Viktor SHEVCHENKO ${ }^{1}$

Galyna KOTSAY ${ }^{2}$

\title{
DETERMINATION OF GLASS WASTE ALLOWABLE AMOUNT USED AS AN ADDITIVE TO PORTLAND CEMENT
}

\begin{abstract}
One of the possible ways of glass waste recycling is its usage as an additive to cement. A great number of authors consider glass a pozzolanic additive due to the high content of $\mathrm{SiO}_{2}$ amorphous phase and suggest to use it instead of cement in amount of $10-30 \%$. However the high content of $\mathrm{R}_{2} \mathrm{O}$ in glass (13-14\%) favors alkaline corrosion in cement and therefore should be limited. In the work was determined of pozzolanic activity for different types glass waste according to Butt J. and EN 196-5:2006. Compared with known mineral additives, such as microsilica and fly ash, glass wastes have very low pozzolanic activity. Therefore, increasing strength in the early stages of hydration cement associated with an alkaline component in a glass additive and not pozzolanic activity of glass waste. To estimate the effect of alkali component in the glass additive we introduced the notion of alkaline activity of cement-glass mixture. Taking as example different types of cement according to the standard PN-EN 197-1:2011 we demonstrate that substitution of neat cement for grinded glass waste is limited due to glass high alkalinity and low pozzolanic activity. The proposed method of the calculation of glass additive allowable amount permits to estimate the glass effect on total alkaline activity of cement compositions at the design stage.
\end{abstract}

Keywords: glass waste, Portland cement, pozzolanic and alkali activity.

\section{Introduction}

Last decade a lot of publications dedicated to the problem of glass waste using as an additive to Portland cement was published. The reason is the constant growth of glass waste. Table 1, according to [1], demonstrates the amount of wastes and their application in different countries .

\footnotetext{
${ }^{1}$ Author for correspondence: Viktor Shevchenko, Institute of Civil Engineering, Warsaw University of Technology, Branch at Plock, Lukashevicha 17, PL-09400 Plock, Poland, Tel.:+48243672239, e-mail: chewchenko4@yahoo.com.

${ }^{2}$ Galyna Kotsay, Institute of Civil Engineering, Warsaw University of Technology, Branch at Plock, Lukashevicha 17, PL-09400 Plock, Poland, Tel.:+48243672121, e-mail: kotsayg@pw.plock.pl.
} 
Table 1. The amount of glass wastes and their application in different countries

Tabela 1. Ilość odpadów szklanych i ich użycie w różnych krajach

\begin{tabular}{|c|c|c|c|c|c|c|c|}
\hline Glass waste & USA & Kanada & Poland [2] & Sweden & Portugal & Germany & Turkey \\
\hline Glass waste, mln tons & 11.5 & 0.116 & 1.5 & 0.239 & 0.493 & 3.2 & 0.12 \\
\hline Recykling glass, \% & 27 & 68 & 60 & 93 & 25 & 94 & 66 \\
\hline
\end{tabular}

Most of publications describe finely grinded glass as a pozzolanic additive introduced instead of Portland cement [3-7]. According to data of different authors the amount of glass waste may vary from 10 to 30\% [5-6]. In Ref. [7] this amount is even $50 \%$ allowing the authors to consider the cement as environmentally friendly product. All authors justify their choice of glass amount by designation of coefficient pozzolanic activity (CPA) which is equal to the ratio between compression strength of the cement mortar with glass and control sample, according to PN-EN 450-1 [8]. If CPA $>75 \%$ relative to the control sample, the glass powder of glass waste is a pozzolanic additive. However, the pozzolanic activity it is ability to react with calcium hydroxide. So not always the strength increase is connected with pozzolanic activity of the additives with amorphous $\mathrm{SiO}_{2}$.

Table 2. Requirements for special cements (NA group) according to PN-B 19707:2012

Tabela 2. Wymagania dla cementów specjalnych (grupy NA) według PN-B 19707:2012

\begin{tabular}{|c|c|c|}
\hline Cement type & The total alkali content, $\%$ & Requirements for cements \\
\hline CEM II/A - V & $\leq 1,2$ & Amount of silica fly ash $\geq 14 \%$ \\
\hline CEM II/A - S & $<1.2$ & Amount of slag $\geq 14 \%$ \\
\hline CEM II/A - M & $\leq 1,2$ & Amount of silica fly ash and slag $\geq 14 \%$ \\
\hline CEM II/B - V & $\leq 1,5$ & Amount of silica fly ash $\geq 25 \%$ \\
\hline CEM II/B - S & $\leq 0,8$ & - \\
\hline CEM II/B - M & $\leq 1,3$ & Amount of silica fly ash $\geq 20 \%$ \\
\hline CEM III/A & $\begin{array}{l}<0.95 \\
<1.10\end{array}$ & $\begin{array}{l}\text { Amount of slag } \leq 49 \% \\
\text { Amount of slag } \geq 50 \%\end{array}$ \\
\hline $\begin{array}{l}\text { CEM III/B } \\
\text { CEM III/C }\end{array}$ & $\leq 2,0$ & - \\
\hline CEM IV/A & $\leq 1,5$ & Amount of silica fly ash $\geq 25 \%$ \\
\hline CEM IV/B & $\leq 2,0$ & - \\
\hline CEM V/A & $\leq 2,0$ & Amount of silica fly ash and slag $\geq 50 \%$ \\
\hline CEM V/B & $\leq 2,0$ & - \\
\hline
\end{tabular}


The great disadvantage of all above-mentioned references is to ignore of alkali factor of glass. It is known that glass contains $13-15 \%$ of $\mathrm{Na}_{2} \mathrm{Oeq}$ (alkali $\mathrm{Na}_{2} \mathrm{O}, \mathrm{K}_{2} \mathrm{O}$ ) that considerably affects the alkalinity of cement mortars and alkaline corrosion of concrete. The total amount of alkali in CEM I Portland cement could not exceed $0.6 \%$ [9] due to the possible alkaline corrosion of the concrete construction [10]. Whereas, for the special cements (low alkaline cement NA group) the alkali content has other limits according to PN-B 19707:2012 [11], tabl. 2.

Therefore, the aim of this work is to determine the allowable amount of glass additive may be used in cement in accordance with PN-EN 197-1:2011 and PN-B 19707:2012 standards.

\section{Materials and investigation methods}

We used container glass waste of the different types. The chemical compositions of the used materials are represented in Table 3.

Table 3. Chemical composition of the different type's glass waste

Tabela 3. Skład chemiczny różnych typów odpadów szklanych

\begin{tabular}{|c|c|c|c|c|c|c|c|c|}
\hline \multirow{2}{*}{ Glass types } & \multicolumn{8}{|c|}{ Oxides, wt \% } \\
\cline { 2 - 9 } & $\mathrm{SiO}_{2}$ & $\mathrm{Al}_{2} \mathrm{O}_{3}$ & $\mathrm{CaO}$ & $\mathrm{MgO}$ & $\mathrm{Na}_{2} \mathrm{Oeq}$ & $\mathrm{Fe}_{2} \mathrm{O}_{3}$ & $\mathrm{Cr}_{2} \mathrm{O}_{3}$ & $\mathrm{SO}_{3}$ \\
\hline colorless & 72.20 & 1.80 & 10.10 & 1.65 & 13.8 & 0.04 & 0.01 & 0.40 \\
\hline green & 71.80 & 1.80 & 10.97 & 1.00 & 13.35 & 0.45 & 0.25 & 0.38 \\
\hline brown & 72.15 & 1.75 & 10.00 & 1.55 & 14.00 & 0.20 & 0.03 & 0.32 \\
\hline
\end{tabular}

Glass crushed and sieved through a sieve of 0.075 .

Pozzolanic activity was determined by two methods. According to the first method [12] the additive was investigated in the additive saturated solution $\mathrm{Ca}(\mathrm{OH})_{2}$ system and the amount of bonded calcium hydroxide per $1 \mathrm{~g}$ of additive was determined for 30 days.

According to the second method [13] the investigations were carried out in the additive-cement-water system. We examined concentration of ions calcium (expressed as $\mathrm{CaO}$ ) and the total alkalinity of the filtrate obtained from aqueous mixture of cement with additive of grinded green glass $(10 \%$ of cement weight). The pozzolanity was determined by comparison of $\mathrm{CaO}$ concentration in the investigated filtrate and in the saturated solution obtained under the same conditions. It is considered that cement meets the requirements of pozzolanic activity if calcium ions concentration in filtrate is lower than that in the saturated solution. 


\section{Results and Discussion}

The possibility of using glass waste as the mineral additive to cement depends on its pozzolanic and alkaline activity. The results of pozzolanic activity investigations according to [12] are represented in Table 4 for different types of glass.

Table 4. Pozzolanic activity for different types of glass

Tabela 4. Aktywność pucolanowej różnych typów szkła

\begin{tabular}{|c|c|}
\hline Glass types & Pozzolanic activity, $\mathrm{mg} \mathrm{CaO} / \mathrm{g}$ additive \\
\hline colorless & 18.9 \\
\hline green & 24.2 \\
\hline brown & 18.1 \\
\hline
\end{tabular}

All types of glass have very low pozzolanic activity (Table 4) compared with known mineral additives, such as microsilica and fly ash [14-15]. At the same time the low pozzolanic activity is confirmed by other chemical method according to PN-EN 196-5:2006. The results of pozzolanic activity of cement with glass waste investigations are represented in Table 5.

Table 5. Pozzolanic activity of cement with glass waste according to [13]

Tabela 5. Aktywność pucolanowej cementu z odpadami szklanymi zgodnie z [13]

\begin{tabular}{|l|c|c|c|c|}
\hline Mixture & $\begin{array}{c}\text { Concentration of } \\
\mathrm{OH}^{-}, \mathrm{mmol} / \mathrm{dm}^{3}\end{array}$ & $\begin{array}{c}\text { Concentration of } \\
\mathrm{CaO} \text { in the filtrate, } \\
\mathrm{mmol} / \mathrm{dm}^{3}\end{array}$ & $\begin{array}{c}\text { Concentration of } \\
\mathrm{CaO}^{*} \text { in the saturated } \\
\text { solution, } \mathrm{mmol} / \mathrm{dm}^{3}\end{array}$ & $\begin{array}{c}\Delta \mathrm{CaO}^{* *}, \\
\mathrm{mmol} / \mathrm{dm}^{3}\end{array}$ \\
\hline $\begin{array}{l}100 \% \text { CEM } \\
\text { I 32,5R }\end{array}$ & 57.3 & 7.2 & 8.3 & 1.1 \\
\hline $\begin{array}{l}90 \% \text { CEM I } \\
32,5 \mathrm{R}+10 \% \\
\text { glass waste }\end{array}$ & 58.1 & 7.2 & 8.1 & 0.9 \\
\hline
\end{tabular}

(*) $\mathrm{CaO}$ calculated according to the formula $\mathrm{C}_{\mathrm{CaO}}{ }^{*}=350 /\left(\mathrm{C}_{\mathrm{OH}-}-15\right)$

$\left(^{* *}\right) \Delta \mathrm{CaO}=\mathrm{C}_{\mathrm{CaO}}{ }^{*}-\mathrm{C}_{\mathrm{CaO}}$

The introduction of glass powder increases the alkalinity of cement mortars but $\mathrm{CaO}$ concentration in the filtrate remains unchanging compared with the control sample. Correspondingly, the results of cement pozzolanic activity are almost the same (standard deviation for calcium ions is $+/-0.2 \mathrm{mmol} / \mathrm{dm}^{3}$ ).

The investigation results of pozzolanity determination allow to conclude that grinded glass is not the pozzolanic additive. However, the strength increase in early terms of hydration allows to consider it such active additive. Probably the strength increase is connected with the increase if alkalinity of cement mortar due to the alkali component in the glass additive [10].

To estimate the effect of alkali component in the glass additive we introduced the notion of alkaline activity of cement-glass mixture (Am). It means the 
total sum of products of $\mathrm{Na}_{2} \mathrm{Oeq}$ amount of each component and its content in the mixture:

$$
\mathrm{Am}=\sum(\mathrm{Ai} * \mathrm{Ki})
$$

where: $\mathrm{A}_{\mathrm{i}}$ - amount of $\mathrm{Na}_{2} \mathrm{Oeq}$ in each component, \%

$\mathrm{K}_{\mathrm{i}}$ - content of each component in the mixture, \%.

On the assumption that $\mathrm{Na}_{2} \mathrm{Oeq}$ amount in cement-glass mixture (Am) cannot exceed the value indicated in PN-B19707 standard the allowable amount of glass powder $(\mathrm{G})$ may be determined according to the formula (2):

$$
\mathrm{G}=(\text { An-Ac) } /(\text { As-Ac }) * 100
$$

where: $\mathrm{G}$ - permissible amount of introduced glass powder, $\%$

An- permissible amount $\mathrm{Na}_{2} \mathrm{Oeq}$ in the cement according to $\mathrm{PN}$ - B 19707, \%

$\mathrm{Ac}$ - amount $\mathrm{Na}_{2} \mathrm{Oeq}$ in the cement, \%

As - amount $\mathrm{Na}_{2} \mathrm{Oeq}$ in the glass, $\%$.

The calculated results of glass powder allowable amount introduced into cement-glass mixture without exceeding standard values of $\mathrm{Na}_{2} \mathrm{Oeq}$ are represented in Table 6.

Table 6 . The activity alkaline of components in the cement-glass mixture

Tabela 6. Aktywność alkaliczna składników w mieszance cementowo - szklanej

\begin{tabular}{|c|c|c|c|c|c|}
\hline $\mathrm{N}$ & Cement types & $\begin{array}{c}\text { Fly ash } \\
\text { content, } \\
\%\end{array}$ & $\begin{array}{c}\text { Slag content, } \\
\%\end{array}$ & $\begin{array}{c}\mathrm{Na}_{2} \text { Oeq content in } \\
\text { cement-glass mixture } \\
(\mathrm{Am}), \%\end{array}$ & $\begin{array}{c}\text { Maximum amount } \\
\text { of glass powder, } \%\end{array}$ \\
\hline 1 & CEM I & - & - & - & 0 \\
\hline 2 & CEM II/A-V & 14.0 & - & 0.83 & 2.92 \\
\hline 3 & CEM II/A-S & - & 14.0 & 0.86 & 2.70 \\
\hline 4 & CEM II/A-M & 10.0 & 10.0 & 0.88 & 2.53 \\
\hline 5 & CEM II/B-V & 28.0 & - & 0.91 & 4.70 \\
\hline 6 & CEM II/B-S & - & 28.0 & 0.96 & 0 \\
\hline 7 & CEM II/B-M & 17.5 & 17.5 & 0.98 & 0.55 \\
\hline 8 & CEM III/A & - & 36.0 & 1.03 & 0 \\
\hline 9 & CEM III/B & - & 73.0 & 1.25 & 5.65 \\
& CEM III/C & - & 88.0 & 1.31 & 4.65 \\
\hline 10 & CEM IV/A & 25.0 & - & 1.43 & 4.80 \\
\hline 11 & CEM IV/B & 45.5 & - & 0.89 & 7.90 \\
\hline 12 & CEM V/A & 25.0 & 25.0 & 1.01 & 7.40 \\
\hline 13 & CEM V/B & 40.0 & 40.0 & 1.08 & 5.80 \\
\hline
\end{tabular}

Notes:

1) amount of alkali in the clinker used for to low alkali cement $\mathrm{NA}\left(\mathrm{Na}_{2} \mathrm{Oeq}<0.75 \%\right)$,

2) amount $\mathrm{Na}_{2} \mathrm{Oeq}$ in the glass $(\approx 13.5 \%)$,

3) amount $\mathrm{Na}_{2} \mathrm{Oeq}$ in the fly ash $(\approx 1.33 \%)$,

4) amount $\mathrm{Na}_{2} \mathrm{Oeq}$ in the slag $(\approx 1.53 \%)$. 
It is known that the alkalinity of cement mortar has a positive influence on the hydration process, especially during pre-induction period, caused by alkali component of the glass powder. However, at the beginning of pre-induction period only alkali cations of the glass grains surface participate in the hydration process. The amount of cations is approximately $6 \%$ relative to the total alkaline content of the glass [16]. While using concrete constructions the glass is dissolved under the action of $\mathrm{Ca}(\mathrm{OH})_{2}$ formed during hydration. The obtained reaction products (ASR effect) [17] are increased in volume and provide tensile strain leading to the appearance of cracks in concrete.

On the basis of obtained results we may conclude that the introduction of great amount of glass waste powder into the cement-glass mixture is dangerous due to its high alkalinity and low pozzolanic activity. For multicomponent cement of CEM II type (PN-EN 197-1:2011) the allowable amount of introduced glass additive does not exceed $4.7 \%$, for CEM III/B and CEM III/C types - from 4.65 to $5.65 \%$. The maximum amount of glass powder till $8 \%$ may be introduced into cement CEM IV/B and CEM V/A. For cements of CEM II/B-S and CEM III/A replacement of cements on finely grinded glass is not recommended.

\section{Conclusions}

Taking as example different types of cement according to the standard PN-EN 197-1:2011 we demonstrate that substitution of neat cement for grinded glass waste is limited due to glass high alkalinity and low pozzolanic activity. The proposed method of the calculation of glass additive allowable amount permits to estimate the glass effect on total alkaline activity of cement compositions at the design stage.

\section{Bibliography}

[1] Jani Y., Holland W.: Waste glass in the production of cement and concrete A review. Journal of Environmental Chemical Engineering. No.2, pp. 1767-1775, 2014.

[2] https://www.mos.gov.pl/ [access 2014].

[3] Shi C., Wu Y., Riefler C., Wang H.: Characteristics and pozzolanic reactivity of glass powders. Cement and Concrete Research. No 35, pp. 987-993, 2005.

[4] Lin K., Wu-Jang-Huang, Shie J., Lee T., Wang K., Lee C.: The utilization of thin film transistor liquid crystal display waste glass a pozzolanic material. Journal of Hazardous Materials. No.163, pp. 916-921, 2009.

[5] Park S., Chun Lee B., Kim J.: Studies on mechanical properties of concrete containing waste glass aggregate. Cement and Concrete Research. No 34, pp.21812189, 2004.

[6] Schwarz N., Cam H., Neithalath N.: Influence of a fine glass powder on the durability characteristics of concrete and its comparison to fly ash. Cement and concrete Composites. No 30, pp 486-496, 2008. 
[7] Sobolev K., Turker P., Soboleva S., Iscioglu G.: Utilization of waste glass in ECOcement: Strength properties and microstructure observations. Waste Management. No 27, pp. 971-976, 2007.

[8] EN 450-1. Fly ash for concrete. Definition, specifications and conformity criteria, 2012.

[9] EN 197-1. Cement, Composition, specifications and conformity criteria for common cements. European Committee for Standardization, 2011.

[10] W. Kurdowski, The chemistry of Cement and Concrete, PWN, Warsaw, 2010 (in polish).

[11] PN-B 19707. Cement. Special cement. Composition, specifications and conformity criteria, 2012.

[12] J. Butt, M. M.Sychev, V.Timashev, Workshop on Chemical Technology binders, Moscow, 1973 (in russian).

[13] EN 196-5. Methods of testing cement - Part 5. Pozzolanic test for pozzolana cements, 2006.

[14] Kotsay G, Szewczenko W. Kompleksowe dodatki do cementu portlandzkiego $\mathrm{z}$ drobnomieonym szkłem odpadowym. Płockie Forum Budowlane, 2012 (in polish) .

[15] Sanytskyy M., Sobol Ch., Markiv T., Modified composite cements, Edition of Lvov Polytechnic National University, Lvov, 2010 (in ukrainian).

[16] Shevchenko V., Kotsay G. Alkaline activity of the glass powders as additives to a Portland cement. Glass Physics and Chemistry. No3, Part II, 2015 (in press).

[17] Shevchenko V., ASR-effect in the glass, used as additives to Portland cement. Glass Physics and Chemistry. No 5, pp. 634-641, 2012 (in russian).

\section{USTALENIE DOPUSZCZALNEJ ILOŚCI ODPADÓW UŻYTYCH JAKO DODATEK DO CEMENTU PORTLANDZKIEGO}

Jednym z możliwych sposobów recyclingu odpadów szklany jest uzycie ich jako dodatek do cementu. Wielu autorów uważa szkło jako dodatek pozzolanowy z powodu wysokiej zawartości $\mathrm{SiO}_{2}$ oraz fazy amorficznej i sugerują jego używanie zamiast cementu w ilości 10-30 \%. Jednakże wysoka zawartość $\mathrm{R}_{2} \mathrm{O}$ w szkle (13-14 \%) powoduje alkaliczną korozję w spoiwie i dlatego zawartość szkła powinna być ograniczona. W pracy ustalono aktywność pocolanową w róznych typach odpadów szklanych według Butt J. i EN 196-5: 2006. Porównanie ze znanymi dodatkami mineralnymi, takimi jak mikrokrzemionka czy popiół lotny wykazało, że odpady szklane mają bardzo niski poziom aktywności pocolanowej. Dlatego, zwiększona wytrzymałość we wczesnej fazie hydratyzacji cementu powiązanego ze składnikiem alkalicznym w dodatku szklanym nie wykazuje aktywności pocolanowej odpadów szklanych. Przy oszacowaniu efektów składników alkalicznych dodatku szklanym zostało wprowadzone pojęcie aktywności alkalicznej mieszanki cementowo-szklanej. Biorąc jako przykład inne rodzaje cementów według normy PN-EN 197-1: 2011 pokazano, że zastępowanie czystego cementu odpadami szklanymi jest ograniczone z powodu wysokiej zasadowości szkła i niskiej aktywności pocolanowej. Zaproponowana metoda obliczania dopuszczalnej ilości dodatku pozwala oszacować wpływ szkła na całkowitą aktywność alkaliczną składników cementu na etapie projektowym.

Słowa kluczowe: odpady szklane, cement portlandzki , aktywność pocolanowa i alkaliczna. 
Przestano do redakcji:26.05.2015

Przyjęto do druku:1.12.2015

DOI: $10.7862 / \mathrm{rb} .2015 .164$ 